\title{
非均相含镍层状双金属氧化物催化异色满与芳伯胺的高效氧化偶联
}

\author{
钱俊峰 田晓婷吴中 姚杰王慧周维友* \\ (常州大学石油化工学院 江苏省绿色催化材料与技术重点实验室 江苏常州 213164)
}

\begin{abstract}
摘要 以非均相 $\mathrm{NiGa}$ 层状双金属氧化物 $\left(\mathrm{Ni}_{3} \mathrm{Ga}-\mathrm{LDO}\right)$ 为催化剂, 催化异色满与芳伯胺的碳氮偶联反应, 可以较高收率 获得碳氮偶联产物. 该催化体系对多种芳伯胺具有较好的适用性. 研究结果表明, 镍物种在氧化偶联过程中起关键作 用，且催化剂具有较优的催化和结构稳定性. 本方法为构建碳氮键提供了一种有效的替代方法.
\end{abstract}

关键词 氧化偶联; 异色满; 芳伯胺; $\mathrm{NiGa}$ 层状双金属氧化物; $\mathrm{C}-\mathrm{N}$ 构建

\section{Efficient Oxidative Coupling of Isochroman with Primary Arylamines Catalyzed by Heterogeneous Ni-Containing Layered Double Oxide}

\author{
Qian, Junfeng Tian, Xiaoting Wu, Zhong Yao, Jie $\quad$ Wang, Hui $\quad$ Zhou, Weiyou* \\ (Jiangsu Key Laboratory of Advanced Catalytic Materials and Technology, Changzhou University, \\ Changzhou, Jiangsu 213164)
}

\begin{abstract}
An efficient heterogeneous catalytic system based on $\mathrm{NiGa}$ layered double oxide ( $\left.\mathrm{Ni}_{3} \mathrm{Ga}-\mathrm{LDO}\right)$ for the $\mathrm{C}-\mathrm{N}$ coupling between isochroman and primary arylamines has been described. Various primary arylamines were tolerated by the catalytic system, and good to excellent yields for the corresponding coupled products could be obtained. The results indicated that $\mathrm{Ni}$ species played the key role in the oxidative cross-coupling process, and the catalyst had good catalytical and structural stability. The protocol provides an effective alternative approach to construct $\mathrm{C}-\mathrm{N}$ bond.
\end{abstract}

Keywords oxidative coupling; isochroman; primary arylamine; $\mathrm{NiGa}$ layered double oxide; $\mathrm{C}-\mathrm{N}$ construction

\section{Introduction}

Construction of carbon-nitrogen bond is quite important in organic synthesis, and many methods have been developed, including amination of alcohol ${ }^{[1]}$ or halohydrocarbon, ${ }^{[2]}$ reductive amination, ${ }^{[3]}$ etc. In the past decade, oxidative cross-coupling reaction has emerged as one of the most attractive strategies for the production of carboncarbon and carbon-heteroatom bonds, featuring high efficiency, simplify and atom-economical green process. ${ }^{[4]}$ Compared with using special nitrogen sources, the direct oxidative cross-coupling of the $\mathrm{C}-\mathrm{H}$ bond with the $\mathrm{N}-\mathrm{H}$ bond has been recognized as a more efficient approach.

$\mathrm{N}$-Phenylisochroman-1-amine derivatives are a class of important compounds with potential bioactivities ${ }^{[5]}$ and serve as important building blocks in synthetic chemistry and drug design. ${ }^{[6]}$ However, only a few methods for the direct amination reactions of the $\mathrm{C}\left(\mathrm{sp}^{3}\right)-\mathrm{H}$ bond adjacent to an oxygen atom using primary amines have been reported. Feng and coworkers ${ }^{[7]}$ have found that the amination of isochroman utilizing DTBP (di-tert-butyl peroxide) as the oxidant could happen in the absence of catalyst, but a high temperature of $120{ }^{\circ} \mathrm{C}$ was required. Chen and co-workers ${ }^{[8]}$ reported a method using iron(II) salt as the catalyst for the direct $\mathrm{C}\left(\mathrm{sp}^{3}\right)-\mathrm{H}$ amination of isochroman derivatives with TBHP (tert-butyl hydroperoxide). However, the protocol was not quite effective for the anilines with strong electron-withdrawing substituents. Subsequently, in our continuous research on the heterogeneous catalytic oxidative cross-coupling reaction, ${ }^{[9]}$ we found that $\mathrm{Ni}$-containing layered double oxide, as a recyclable heterogeneous catalyst, could effectively accelerate the coupling reaction between isochroman and primary amines under relatively mild conditions, which would provide an efficient alternative protocol to synthesize $N$-phenylisochroman-1-amine derivatives.

* Corresponding author. E-mail: zhouwy426@126.com

Received April 10, 2021; revised June 7, 2021; published online June 15, 2021.

Project supported by the Jiangsu Key Laboratory of Advanced Catalytic Materials and Technology (No. BM2012110), the Natural Science Foundation for Colleges and Universities in Jiangsu Province (No. 20KJA530003), and the Jiangsu Key Laboratory of Biomass Energy and Material (No. JSBEM202018). 江苏省绿色催化材料与技术重点实验室基金(No. BM2012110)、江苏省高等学校自然科学研究重大项目(No. 20KJA530003)、江苏省生物质能源与材 料重点实验室基金(No. JSBEM202018)资助项目. 


\section{Results and discussion}

The reaction conditions using isochroman and aniline as the model substrates were initially optimized. Various $\mathrm{Ni}$-containing hydrotalcites were investigated in the reaction, and $\mathrm{Ni}_{3} \mathrm{Ga}$-LDO exhibited the highest catalytic activity and selectivity to the coupled product 3a. The main byproduct was the over-oxidation product 2-phenyl-3, 4-dihydroisoquinolin-1(2H)-one (4). Screening of the solvents indicated that 1,1,2,2-tetrachloroethane gave the highest conversion with moderate selectivity of 3a. Subsequently, some other oxidants including DTBP, $\mathrm{NaS}_{2} \mathrm{O}_{8}$ and molecular oxygen, were used instead of TBHP, but only trace of the substrate could transform under the selected conditions. When 2 equiv. of $\mathbf{2 a}$ was introduced into the system, the conversion elevated to $77 \%$ with $70 \%$ selectivity to 3a. Further increasing the amount of $\mathbf{2 a}$ significantly decreased the selectivity. When the reaction was conducted at $60{ }^{\circ} \mathrm{C}$, only a $60 \%$ conversion was obtained, whilst high temperature also resulted in the decreased conversion, which might be related to the decomposition of TBHP under high temperature. Increasing the amount of TBHP could improve the yield of $\mathbf{3 a}$ to some extent, and prolonging the reaction time to $24 \mathrm{~h}$ resulted in a $77 \%$ selectivity to $\mathbf{3 a}$ with an $86 \%$ conversion. Although the con- version of 1a could further elevate in the case of $30 \mathrm{~h}$, the selectivity to 3a significantly decreased. In summary, the coupling reaction between isochroman and aniline could smoothly proceed with satisfying yield under the catalysis of $\mathrm{Ni}_{3} \mathrm{Ga}-\mathrm{LDO}$ in the presence of TBHP.

With the optimized reaction conditions in hand, various anilines have been introduced into the reaction to test the scope of substrate (Table 2). When methyl or ethyl group locating at the para-site of the anilines, good yields of the coupled products could be obtained $(\mathbf{3 b} \sim \mathbf{3 c})$. Substrates with methyl at the ortho- or meta-site could also be well tolerated $(\mathbf{3} \mathbf{d} \sim \mathbf{3 e})$. Concerning the reaction times and yields for the substrates with methyl at different sites of the aniline, it can be deduced that the effect of steric hindrance exists in the reaction. Methoxyl substituted at para- and meta-sites improved the reactivity in terms of the reaction time $(\mathbf{3 f} \sim \mathbf{3 g})$, giving the coupled products in yields of $72 \%$ and $62 \%$, respectively. The substrates with halogen substituents could also work well under the standard reaction conditions, and good to excellent yields of the coupled product could be obtained $(\mathbf{3 h} \sim \mathbf{3 m})$. Furtherly, anilines with cyano, nitro and trifluoro locating at the para- or ortho-sites could also give satisfactory isolated yield, although the prolonging reaction times were required $(\mathbf{3 n} \sim$

Table 1 Optimization of the reaction conditions ${ }^{a}$
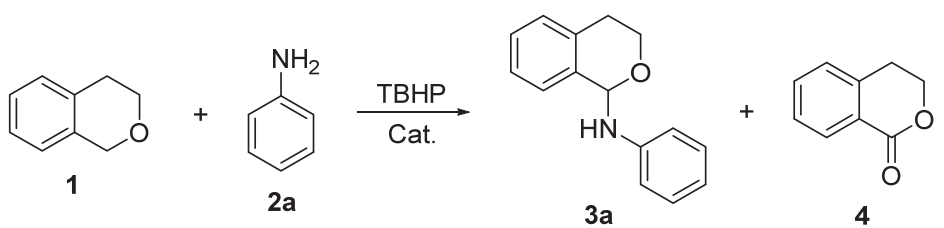

\begin{tabular}{|c|c|c|c|c|c|c|c|}
\hline Entry & Catalyst & Solvent & Oxidant & $2 a / 1$ & Temp. $/{ }^{\circ} \mathrm{C}$ & Conv. ${ }^{b} / \%$ & Sel. ${ }^{b} / \%$ \\
\hline 1 & $\mathrm{Ni}_{3} \mathrm{Ga}-\mathrm{LDH}$ & Toluene & ТВНP & 1 & 80 & 42 & 50 \\
\hline 2 & $\mathrm{Ni}_{3} \mathrm{Ga}-\mathrm{LDO}$ & Toluene & ТВHP & 1 & 80 & 65 & 58 \\
\hline 3 & $\mathrm{Ni}_{3} \mathrm{Al}-\mathrm{LDO}$ & Toluene & ТВHP & 1 & 80 & 60 & 34 \\
\hline 4 & Ni3 In-LDO & Toluene & ТВHP & 1 & 80 & 44 & 25 \\
\hline 5 & $\mathrm{Ni}_{3} \mathrm{Ga}-\mathrm{LDO}$ & Acetonitrile & ТВНP & 1 & 80 & 80 & 28 \\
\hline 6 & $\mathrm{Ni}_{3} \mathrm{Ga}-\mathrm{LDO}$ & Dioxane & ТВHP & 1 & 80 & 79 & 37 \\
\hline 7 & $\mathrm{Ni}_{3} \mathrm{Ga}-\mathrm{LDO}$ & Methanol & ТВНР & 1 & 80 & 60 & 28 \\
\hline 8 & $\mathrm{Ni}_{3} \mathrm{Ga}-\mathrm{LDO}$ & $\mathrm{H}_{2} \mathrm{O}$ & ТВНР & 1 & 80 & Trace & - \\
\hline 9 & $\mathrm{Ni}_{3} \mathrm{Ga}-\mathrm{LDO}$ & DMSO & ТВНР & 1 & 80 & Trace & - \\
\hline 10 & $\mathrm{Ni}_{3} \mathrm{Ga}-\mathrm{LDO}$ & 1,1,2,2-Tetrachloroethane & ТВHP & 1 & 80 & 73 & 60 \\
\hline 11 & $\mathrm{Ni}_{3} \mathrm{Ga}-\mathrm{LDO}$ & $1,1,2,2$-Tetrachloroethane & DTBP & 1 & 80 & Trace & - \\
\hline 12 & $\mathrm{Ni}_{3} \mathrm{Ga}-\mathrm{LDO}$ & 1,1,2,2-Tetrachloroethane & $\mathrm{Na}_{2} \mathrm{~S}_{2} \mathrm{O}_{8}$ & 1 & 80 & Trace & - \\
\hline 13 & $\mathrm{Ni}_{3} \mathrm{Ga}-\mathrm{LDO}$ & $1,1,2,2$-Tetrachloroethane & $\mathrm{O}_{2}$ & 1 & 80 & Trace & - \\
\hline 14 & $\mathrm{Ni}_{3} \mathrm{Ga}-\mathrm{LDO}$ & $1,1,2,2$-Tetrachloroethane & TBHP & 2 & 80 & 77 & 70 \\
\hline 15 & $\mathrm{Ni}_{3} \mathrm{Ga}-\mathrm{LDO}$ & $1,1,2,2$-Tetrachloroethane & ТВНP & 4 & 80 & 82 & 48 \\
\hline 16 & $\mathrm{Ni}_{3} \mathrm{Ga}-\mathrm{LDO}$ & $1,1,2,2$-Tetrachloroethane & ТВHP & 2 & 60 & 60 & 40 \\
\hline 17 & $\mathrm{Ni}_{3} \mathrm{Ga}-\mathrm{LDO}$ & $1,1,2,2$-Tetrachloroethane & ТВHP & 2 & 100 & 72 & 64 \\
\hline $18^{c}$ & $\mathrm{Ni}_{3} \mathrm{Ga}-\mathrm{LDO}$ & $1,1,2,2$-Tetrachloroethane & ТВНР & 2 & 80 & 82 & 75 \\
\hline $19^{d}$ & $\mathrm{Ni}_{3} \mathrm{Ga}-\mathrm{LDO}$ & 1,1,2,2-Tetrachloroethane & ТВHP & 2 & 80 & 94 & 34 \\
\hline $20^{c, e}$ & $\mathrm{Ni}_{3} \mathrm{Ga}-\mathrm{LDO}$ & $1,1,2,2$-Tetrachloroethane & ТВHР & 2 & 80 & 86 & 77 \\
\hline $21^{c, f}$ & $\mathrm{Ni}_{3} \mathrm{Ga}-\mathrm{LDO}$ & 1,1,2,2-Tetrachloroethane & ТВНР & 2 & 80 & 92 & 70 \\
\hline
\end{tabular}

${ }^{a}$ Reaction conditions: $10.5 \mathrm{mmol}, \mathrm{Ni}_{3} \mathrm{Ga}-\mathrm{LDO} 0.1 \mathrm{~g}$, reaction time $16 \mathrm{~h}$, solvent $2 \mathrm{~mL}, \mathrm{~N}_{2}$ atmosphere. ${ }^{b}$ Based on the ${ }^{1} \mathrm{H}$ NMR analysis $(0.1 \mathrm{mmol} 1,4-$ dinitrobenzene was used as the internal standard reference), selectivity to $3 \mathbf{a}$, and the by-products were not quantified. ${ }^{c} 4$ equiv. of TBHP. ${ }^{d} 6$ equiv. of TBHP. ${ }^{e} 24$ h. ${ }^{f} 30$ h. 
Table 2 Reaction of isochroman with various anilines over $\mathrm{Ni}_{3} \mathrm{Ga}-\mathrm{LDO}^{a}$
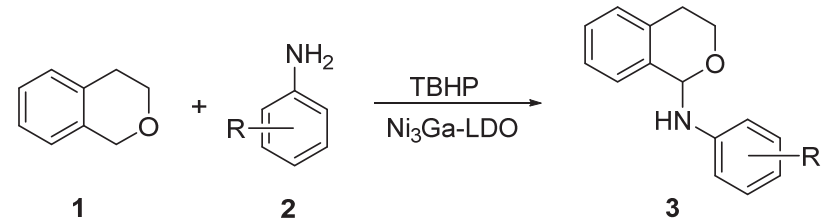

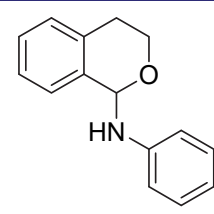

3a, 24 h, $62 \%$<smiles>COc1ccc(NC2OCCc3ccccc32)cc1</smiles>

3f, $20 \mathrm{~h}, 72 \%$<smiles>Ic1ccc(NC2OCCc3ccccc32)cc1</smiles>

3k, 24 h, $67 \%$

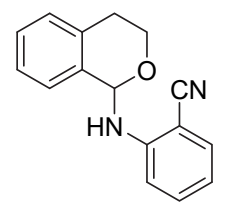

$3 p, 28$ h, $64 \%$

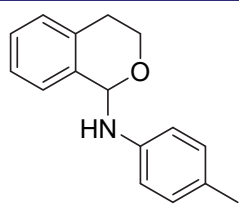

3b, 20 h, $68 \%$

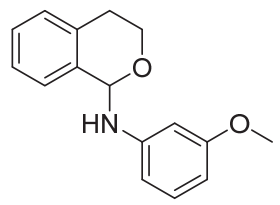

$3 g, 20$ h, $62 \%$

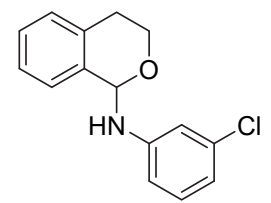

3I, $24 \mathrm{~h}, 51 \%$

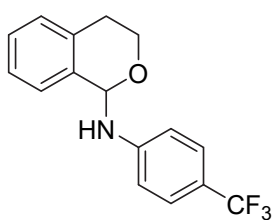

$3 q, 28$ h, $67 \%$

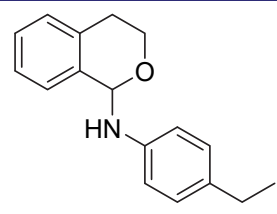

3c, $20 \mathrm{~h}, 70 \%$<smiles>Fc1ccc(NC2OCCc3ccccc32)cc1</smiles>

$3 h, 24$ h, $63 \%$<smiles>Brc1cccc(NC2OCCc3ccccc32)c1</smiles>

$3 \mathrm{~m}, 24 \mathrm{~h}, 55 \%$<smiles>Clc1cc(Cl)cc(NC2OCCc3ccccc32)c1</smiles>

$3 r, 28$ h, $59 \%$

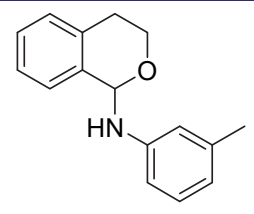

3d, 24 h, $63 \%$<smiles>Clc1ccc(NC2OCCc3ccccc32)cc1</smiles>

$3 i, 24$ h, $62 \%$<smiles>O=[N+]([O-])c1ccccc1NC1OCCc2ccccc21</smiles>

3n, 28 h, $55 \%$

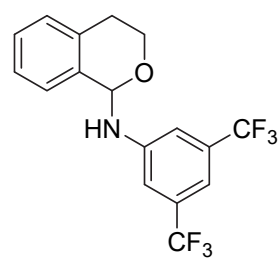

3s, $28 \mathrm{~h}, 65 \%$

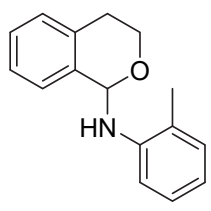

3e, 24 h, $60 \%$<smiles>Brc1ccc(NC2OCCc3ccccc32)cc1</smiles>

3j, 24 h, $60 \%$<smiles>N#Cc1ccc(NC2OCCc3ccccc32)cc1</smiles>

3o, $28 \mathrm{~h}, 69 \%$

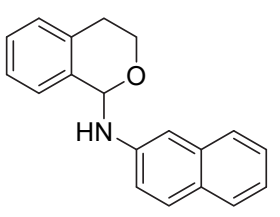

3t, 24 h, $58 \%$

${ }^{a}$ Reaction conditions: $10.5 \mathrm{mmol}, 21.0 \mathrm{mmol}, \mathrm{Ni}_{3} \mathrm{Ga}$-LDO $0.1 \mathrm{~g}$, TBHP $2.0 \mathrm{mmol}, 80{ }^{\circ} \mathrm{C}, 1,1,2,2$-tetrachloroethane $2 \mathrm{~mL}, \mathrm{~N}_{2}$ atmosphere

3q). These anilines with strong electron-withdrawing groups could not give the desired product in the reported $\mathrm{FeCl}_{3}$ /TBHP system. The researchers ascribed the result to the instability of isochroman in the weak acidic conditions, that are present when anilines with strong electron-withdrawing groups are used. ${ }^{[8]}$ In the present catalytic system, $\mathrm{Ni}_{3} \mathrm{Ga}-\mathrm{LDO}$, as a typical base material, might provide a basic conditions for the reaction. The observations also demonstrated that electron-withdrawing groups reduced the reactivity, because they required longer reaction times to complete the reaction. Finally, some substrates with two substituents were investigated in the reaction system. The results showed that dichloro aniline or ditrifluoromethyl aniline could be well tolerated by the catalytic system, and good yields of the product were obtained $(3 \mathbf{r} \sim 3 \mathbf{s}) . \mathrm{N}$ Methylaniline, diphenylamine and some aliphatic amines, such as $n$-butylamine, cyclohexylamine, benzylamine and 4-aminopyridine, were also applied in this reaction, but no desired product was obtained. These observations probably be due to their sensitivity to oxidization. Applying benzamide did not give the coupled product, which might be ascribed to its low nucleophilic activity. 2-Naphthylamine was also tested in the catalytic system, and satisfactory yield to the corresponding coupled product could be obtained (3t).

One of the advantages for heterogeneous catalysis is its good recyclability. Therefore, the catalyst was separated by filtration, washed with 1,1,2,2-tetrachloroethane and then ethyl acetate, calcined at $400{ }^{\circ} \mathrm{C}$ for $4 \mathrm{~h}$ and introduced into a new reaction to recycle the catalyst. The results show that only slight reduction of activity could be observed for the catalyst even after five runs (Figure 1), and almost no change of the selectivity. The possible leaching of metals in the filtrate of the reaction residues was analyzed by inductively coupled plasma (ICP) after the reaction. The results indicate that only trace of $\mathrm{Ni}$ and $\mathrm{Ga}$ was detected, implying that leaching of metals could be ignored. XRD pattern for the reused catalyst indicates that the structure of the $\mathrm{Ni}_{3} \mathrm{Ga}-\mathrm{LDO}$ did not changed after several reuses, and the diffractive peaks for layered double oxide still retained (Figure S1). These observations strongly indicate the excellent structural and catalytic stability of 
the $\mathrm{Ni}_{3} \mathrm{Ga}$-LDO catalyst during the amination of isochroman with anilines under the present conditions.

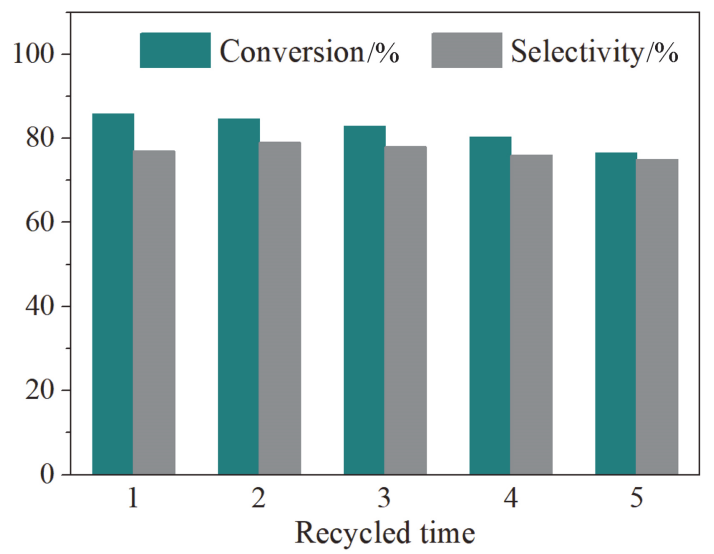

Figure 1 Recycled results for $\mathrm{Ni}_{3} \mathrm{Ga}-\mathrm{LDO}$ in the coupling reaction

Reaction conditions: $10.5 \mathrm{mmol}$, 2a $1.0 \mathrm{mmol}, \mathrm{Ni}_{3} \mathrm{Ga}-\mathrm{LDO} 0.1 \mathrm{~g}$, TBHP $2.0 \mathrm{mmol}, 80{ }^{\circ} \mathrm{C}, 24 \mathrm{~h}, 1,1,2,2$-tetrachloroethane $2 \mathrm{~mL}, \mathrm{~N}_{2}$ atmosphere

To get insight of the catalytic coupling reaction between isochroman and primary arylamines, a series of controlled experiments have been performed under the selected conditions (Table 3). Without catalyst, significantly decreased conversion and selectivity were observed, indicating the catalytic function of $\mathrm{Ni}_{3} \mathrm{Ga}-\mathrm{LDO}$. When the reaction was conducted in the air atmosphere, the selectivity decreased markedly, and compound $\mathbf{4}$ was formed as the main by-product, implying that the presence of molecular oxygen would lead to oxygenated product. Some other catalysts were also introduced into the reaction for comparison. When $\mathrm{Mg}_{3} \mathrm{Ga}$-LDO was used as the catalyst, only trace of 1 converted, and $\mathrm{Ni}_{2}(\mathrm{AcO})_{2}$ could give high conversion but with quite low selectivity to $\mathbf{3 a}$. These results indicate that $\mathrm{Ni}$ species should be the catalytic center, and the layered double oxide (LDO) structure benefits to the formation of coupling product. Introduction of two equivalent of 2,6-ditert-butyl-4-methylphenol (BHT) or 2,2,6,6-tetramethylpiperidine-1-oxyl (TEMPO) as a radical scavenger into the reaction led to quite lower conversion of the substrate or the selectivity, implying that a radical pathway is probably involved in the $\mathrm{Ni}_{3} \mathrm{Ga}-\mathrm{LDO}$ catalyzed coupling reaction.

According to the above results and the literature, ${ }^{[7-9]} \mathrm{a}$ plausible mechanism has been proposed (Scheme 1). TBHP decomposes into the tert-butoxyl radical and hydroxyl anion in the presence of the $\mathrm{Ni}_{3} \mathrm{Ga}$-LDO. A hydrogen abstraction of the $\mathrm{C}-\mathrm{H}$ bond adjacent to oxygen atom of isochroman affords intermediate $\mathbf{I}$, which is further oxidized to $\mathbf{I I}$ by $\mathrm{Ni}_{3} \mathrm{Ga}-\mathrm{LDO}$. Aniline then reacts with $\mathbf{I I}$ to give the desired $\mathrm{C}-\mathrm{N}$ coupling product $\mathbf{3 a}$ with the release of $\mathrm{H}^{+}$.

\section{Conclusions}

In summary, we have successfully realized the direct oxidative cross-coupling of isochroman with various arylamines over $\mathrm{Ni}_{3} \mathrm{Ga}$-LDO catalyst under relatively mild reaction conditions. The heterogeneous catalytic system will provide a more environmentally friendly and economic alternative protocol for the $\mathrm{C}-\mathrm{N}$ formation.

Table 3 Catalytic results under different reaction conditions ${ }^{a}$
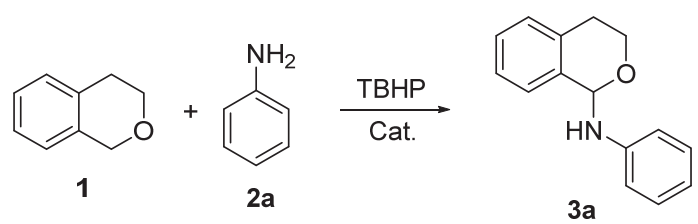

\begin{tabular}{|c|c|c|c|c|}
\hline Entry & Catalyst & Additive & Conv. ${ }^{b} / \%$ & $\mathrm{Sel}^{b} / \%$ \\
\hline 1 & $\mathrm{Ni}_{3} \mathrm{Ga}-\mathrm{LDO}$ & - & 86 & 77 \\
\hline 2 & - & - & 52 & 38 \\
\hline $3^{c}$ & $\mathrm{Ni}_{3} \mathrm{Ga}-\mathrm{LDO}$ (air) & - & 79 & 13 \\
\hline 4 & $\mathrm{Mg}_{3} \mathrm{Ga}-\mathrm{LDO}$ & - & Trace & - \\
\hline $5^{d}$ & $\mathrm{Ni}_{2}(\mathrm{AcO})_{2}$ & - & 76 & 39 \\
\hline 6 & $\mathrm{Ni}_{3} \mathrm{Ga}-\mathrm{LDO}$ & $\mathrm{BHT}^{e}$ & 13 & 63 \\
\hline 7 & $\mathrm{Ni}_{3} \mathrm{Ga}-\mathrm{LDO}$ & TEMPO $^{e}$ & 82 & 52 \\
\hline
\end{tabular}

${ }^{a}$ Reaction conditions: $10.5 \mathrm{mmol}, 2 \mathrm{a} 1.0 \mathrm{mmol}$, catalyst $0.1 \mathrm{~g}$, TBHP 2.0 mmol, $80{ }^{\circ} \mathrm{C}, 24 \mathrm{~h}, 1,1,2,2$-tetrachloroethane $2 \mathrm{~mL}, \mathrm{~N}_{2}$ atmosphere. ${ }^{b}$ Based on the ${ }^{1} \mathrm{H}$ NMR analysis $(0.1 \mathrm{mmol}$ of 1,4 -dinitrobenzene was used as the internal standard reference), and the by-products were not quantified. ${ }^{c}$ Under air atmosphere. ${ }^{d} 0.025$ mmol. ${ }^{e} 2$ equiv.

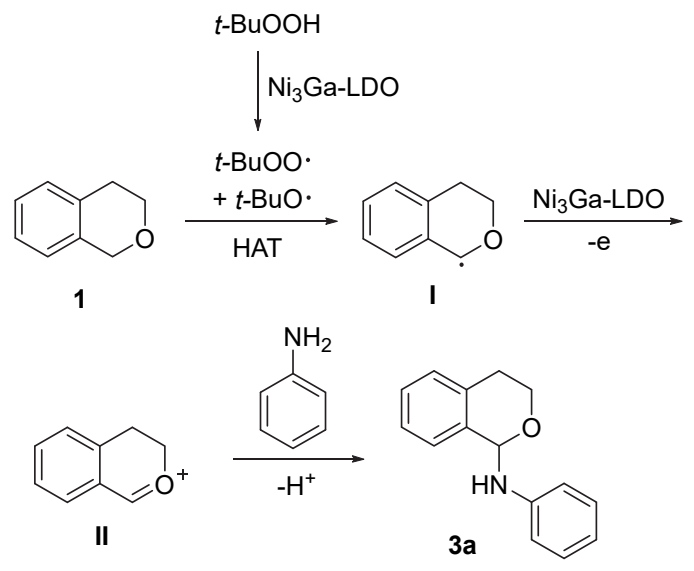

Scheme 1 Proposed reaction pathways

\section{Experimental section}

\subsection{General information}

All the chemicals were purchased from Energy or Aladdin. Unless otherwise specified, reagents and solvents were used as received. Reactions were monitored by thin layer chromatography (TLC) using silica gel F254 plates. The conversion of the substrate and the selectivity of coupling products were obtained on the basis of the ${ }^{1} \mathrm{H}$ NMR analysis (1,4-dinitrobenzene was used as the internal standard reference). Products were purified using flash chromatography over $300 \sim 400$ mesh silica gel under a positive pressure of air. NMR spectra were recorded at $25{ }^{\circ} \mathrm{C}$ on an Bruker AVANCE III 400-NMR spectrometer at 400 $\mathrm{MHz}$ for ${ }^{1} \mathrm{H} \mathrm{NMR}$ and $100 \mathrm{MHz}$ for ${ }^{13} \mathrm{C} \mathrm{NMR}$ using $\mathrm{CDCl}_{3}$ as solvent with TMS as the internal standard. The FTIR spectra were analyzed on a Nicolet PROTÉGÉ 460 FTIR spectrometer. High-resolution mass spectra (HRMS) 
were obtained using an Agilent 6546 Q-TOF spectrometer (ESI).

\subsection{General procedure for the preparation of cata- lysts}

$\mathrm{Ni}_{3} \mathrm{Ga}$ layered double oxide $\left(\mathrm{Ni}_{3} \mathrm{Ga}-\mathrm{LDO}\right)$ was prepared using the corresponding hydrotalcite $\left(\mathrm{Ni}_{3} \mathrm{Ga}-\mathrm{LDH}\right)$ as the precursor. $\mathrm{Ni}_{3} \mathrm{Ga}-\mathrm{LDH}$ was prepared through a coprecipitation method. A solution of $\mathrm{Ni}\left(\mathrm{NO}_{3}\right)_{2} \cdot 6 \mathrm{H}_{2} \mathrm{O}(0.066 \mathrm{~mol})$ and $\mathrm{Ga}\left(\mathrm{NO}_{3}\right)_{3} \bullet 8 \mathrm{H}_{2} \mathrm{O}(0.022 \mathrm{~mol})$ in deionized water $(100$ $\mathrm{mL})$ and the other solution of $\mathrm{Na}_{2} \mathrm{CO}_{3}(0.1 \mathrm{~mol})$ and $\mathrm{NaOH}$ $(0.2 \mathrm{~mol})$ in deionized water $(100 \mathrm{~mL})$ were dropped into $100 \mathrm{~mL}$ of deionized water in a $500 \mathrm{~mL}$ flask under vigorous stirring at $25{ }^{\circ} \mathrm{C}$. The dropping speed was controlled to maintain the $\mathrm{pH}$ value at $10 \pm 0.5$. After that, the solution was stirred at $70{ }^{\circ} \mathrm{C}$ for $8 \mathrm{~h}$, then aged at room temperature for $12 \mathrm{~h}$. After being filtered, washed with deionized water, dried at $120{ }^{\circ} \mathrm{C}$ overnight, $\mathrm{Ni}_{3} \mathrm{Ga}-\mathrm{LDH}$ was obtained. Calcining $\mathrm{Ni}_{3} \mathrm{Ga}-\mathrm{LDH}$ under $400{ }^{\circ} \mathrm{C}$ for $4 \mathrm{~h}$ gave the sample $\mathrm{Ni}_{3} \mathrm{Ga}-\mathrm{LDO}$. Through the similar method, $\mathrm{Mg}_{3} \mathrm{Ga}-\mathrm{LDO}, \mathrm{Ni}_{3} \mathrm{Al}$-LDO and $\mathrm{Ni}_{3} \mathrm{In}$-LDO were obtained. The structures of these samples were analyzed using Powder X-ray diffraction (XRD) on a Rigaku D/max 2500 PC $\mathrm{X}$-ray diffractometer using $\mathrm{Cu}-\mathrm{K} \alpha$ radiation.

\subsection{General procedure for the coupling reaction over $\mathrm{Ni}_{3} \mathrm{Ga}$-LDO}

Taking the cross-coupling reaction of isochraman 1 with aniline $\mathbf{2 a}$ as an example. Isochroman $(0.50 \mathrm{mmol})$, aniline (1.0 mmol), $\mathrm{Ni}_{3} \mathrm{Ga}-\mathrm{LDO}(0.1 \mathrm{~g})$, TBHP $(2.0 \mathrm{mmol})$ and 1,1,2,2-tetrachloroethane $(2 \mathrm{~mL})$ were mixed in a carousel reaction tube. The reaction mixture was stirred at $80{ }^{\circ} \mathrm{C}$ under nitrogen atmosphere, the reaction was sampled periodically and monitored by TLC (petroleum ether/ethyl acetate, $V: V=10: 1)$. The conversion of the substrate and the selectivity of coupling products were obtained on the basis of the ${ }^{1} \mathrm{HNMR}$ analysis (1,4-dinitrobenzene was used as the internal standard reference). After the reaction, the reaction mixture was then cooled to room temperature and purified using flash chromatography (petroleum ether/ethyl acetate, $V: V=10: 1$ ) to give a yellow oil, yield $62 \%$.

$N$-Phenylisochroman-1-amine (3a): ${ }^{[7-8]}$ Yellow oil. ${ }^{1} \mathrm{H}$ NMR $\left(300 \mathrm{MHz}, \mathrm{CDCl}_{3}\right) \delta: 7.33 \sim 7.17(\mathrm{~m}, 6 \mathrm{H}), 6.89 \sim$ $6.79(\mathrm{~m}, 3 \mathrm{H}), 6.06(\mathrm{~d}, J=7.0 \mathrm{~Hz}, 1 \mathrm{H}), 4.57(\mathrm{~d}, J=6.2 \mathrm{~Hz}$, $1 \mathrm{H}), 4.15$ (ddd, $J=11.7,9.5,4.1 \mathrm{~Hz}, 1 \mathrm{H}), 3.91$ (ddd, $J=$ $11.6,5.5,4.0 \mathrm{~Hz}, 1 \mathrm{H}), 3.02 \sim 2.91(\mathrm{~m}, 1 \mathrm{H}), 2.76(\mathrm{dt}, J=$ 16.6, $3.9 \mathrm{~Hz}, 1 \mathrm{H}) ;{ }^{13} \mathrm{C} \mathrm{NMR}\left(75 \mathrm{MHz}, \mathrm{CDCl}_{3}\right) \delta: 146.0$, $135.7,135.2,129.6,129.2,128.2,127.1,126.7,119.2$, 114.2, 80.5, 58.6, 28.6. HRMS (ESI ${ }^{+}$) calcd for $\mathrm{C}_{15} \mathrm{H}_{16} \mathrm{NO}$ $[\mathrm{M}+\mathrm{H}]^{+}$226.1226, found 226.1227.

$N$-(p-Tolyl)isochroman-1-amine (3b): $:{ }^{[7-8]}$ Yellow oil. ${ }^{1} \mathrm{H}$ NMR $\left(500 \mathrm{MHz}, \mathrm{CDCl}_{3}\right) \delta: 7.33(\mathrm{~d}, J=7.4 \mathrm{~Hz}, 1 \mathrm{H})$, $7.29 \sim 7.25(\mathrm{~m}, 2 \mathrm{H}), 7.19(\mathrm{~d}, J=7.3 \mathrm{~Hz}, 1 \mathrm{H}), 7.08(\mathrm{~d}, J=$ $8.1 \mathrm{~Hz}, 2 \mathrm{H}), 6.82(\mathrm{~d}, J=8.2 \mathrm{~Hz}, 2 \mathrm{H}), 6.07(\mathrm{~d}, J=7.7 \mathrm{~Hz}$, $1 \mathrm{H}), 4.49(\mathrm{~d}, J=7.1 \mathrm{~Hz}, 1 \mathrm{H}), 4.18(\mathrm{dd}, J=14.4,6.6 \mathrm{~Hz}$, $1 \mathrm{H}), 3.95 \sim 3.91(\mathrm{~m}, 1 \mathrm{H}), 3.02 \sim 2.96(\mathrm{~m}, 1 \mathrm{H}), 2.79(\mathrm{~d}, J=$ $16.5 \mathrm{~Hz}, 1 \mathrm{H}), 2.30(\mathrm{~s}, 3 \mathrm{H}) ;{ }^{13} \mathrm{C} \mathrm{NMR}\left(125 \mathrm{MHz}, \mathrm{CDCl}_{3}\right) \delta$ :
$143.6,135.9,135.2,130.0,129.1,128.1,127.1,126.7$, $114.3,80.8,58.5,28.6,20.8$. HRMS $\left(\mathrm{ESI}^{+}\right)$calcd for $\mathrm{C}_{16} \mathrm{H}_{18} \mathrm{NO}[\mathrm{M}+\mathrm{H}]^{+}$240.1383, found 240.1383.

$N$-(4-Ethylphenyl)isochroman-1-amine (3c) ${ }^{[8]}$ Yellow oil. ${ }^{1} \mathrm{H}$ NMR $\left(500 \mathrm{MHz}, \mathrm{CDCl}_{3}\right) \delta: 7.36 \sim 7.23(\mathrm{~m}, 4 \mathrm{H})$, $7.11(\mathrm{~d}, J=8.4 \mathrm{~Hz}, 2 \mathrm{H}), 6.85(\mathrm{~d}, J=8.4 \mathrm{~Hz}, 2 \mathrm{H}), 6.08$ (d, $J=7.8 \mathrm{~Hz}, 1 \mathrm{H}), 4.51(\mathrm{~d}, J=7.8 \mathrm{~Hz}, 1 \mathrm{H}), 4.18$ (ddd, $J=$ 11.7, 9.6, 4.0 Hz, 1H), 3.93 (ddd, $J=11.6,5.5,3.9 \mathrm{~Hz}$, $1 \mathrm{H}), 3.03 \sim 2.96(\mathrm{~m}, 1 \mathrm{H}), 2.81 \sim 2.77(\mathrm{~m}, 1 \mathrm{H}), 2.62 \sim 2.58$ $(\mathrm{m}, 2 \mathrm{H}), 1.24(\mathrm{~s}, 3 \mathrm{H}) ;{ }^{13} \mathrm{C} \mathrm{NMR}\left(125 \mathrm{MHz}, \mathrm{CDCl}_{3}\right) \delta$ : $143.8,135.9,135.2,135.1,128.9,128.1,127.1,126.7$, $114.2,80.8,58.5,28.6,16.3$. HRMS $\left(\mathrm{ESI}^{+}\right)$calcd for $\mathrm{C}_{17} \mathrm{H}_{20} \mathrm{NO}[\mathrm{M}+\mathrm{H}]^{+}$254.1539, found 254.1539.

$N$-(m-Tolyl)isochroman-1-amine (3d): ${ }^{[8]}$ Yellow oil. ${ }^{1} \mathrm{H}$ NMR $\left(500 \mathrm{MHz}, \mathrm{CDCl}_{3}\right) \delta: 7.34 \sim 7.26(\mathrm{~m}, 3 \mathrm{H}), 7.21 \sim$ $7.15(\mathrm{~m}, 2 \mathrm{H}), 6.78 \sim 6.67(\mathrm{~m}, 3 \mathrm{H}), 6.10(\mathrm{~d}, J=7.7 \mathrm{~Hz}$, $1 \mathrm{H}), 4.57$ (d, $J=7.6 \mathrm{~Hz}, 1 \mathrm{H}), 4.19$ (ddd, $J=11.6,9.7,4.0$ $\mathrm{Hz}, 1 \mathrm{H}), 3.95$ (ddd, $J=11.6,5.5,3.8 \mathrm{~Hz}, 1 \mathrm{H}), 3.05 \sim 2.97$ $(\mathrm{m}, 1 \mathrm{H}), 2.82 \sim 2.76(\mathrm{~m}, 1 \mathrm{H}), 2.36(\mathrm{~s}, 3 \mathrm{H}) ;{ }^{13} \mathrm{C}$ NMR $(125$ $\left.\mathrm{MHz}, \mathrm{CDCl}_{3}\right) \delta: 146.0,139.4,135.8,135.2,129.5,129.1$, $128.2,127.1,126.7,120.1,114.8,111.4,80.5,58.5,28.5$, 21.9. HRMS $\left(\mathrm{ESI}^{+}\right)$calcd for $\mathrm{C}_{16} \mathrm{H}_{18} \mathrm{NO}[\mathrm{M}+\mathrm{H}]^{+}$ 240.1383 , found 240.1383 .

$N$-(o-Tolyl)isochroman-1-amine (3e): ${ }^{[7]}$ Yellow oil. ${ }^{1} \mathrm{H}$ NMR $\left(500 \mathrm{MHz}, \mathrm{CDCl}_{3}\right) \delta: 7.32 \sim 7.27(\mathrm{~m}, 5 \mathrm{H}), 7.18(\mathrm{~s}$, $1 \mathrm{H}), 7.14(\mathrm{~d}, J=7.3 \mathrm{~Hz}, 1 \mathrm{H}), 6.81(\mathrm{td}, J=7.3,1.0 \mathrm{~Hz}$, $1 \mathrm{H}), 6.13(\mathrm{~d}, J=7.5 \mathrm{~Hz}, 1 \mathrm{H}), 4.45(\mathrm{~d}, J=7.4 \mathrm{~Hz}, 1 \mathrm{H}), 4.19$ (ddd, $J=11.7,9.4,4.0 \mathrm{~Hz}, 1 \mathrm{H}), 3.98 \sim 3.93(\mathrm{~m}, 1 \mathrm{H})$, $3.03 \sim 2.98(\mathrm{~m}, 1 \mathrm{H}), 2.83(\mathrm{dt}, J=16.5,4.0 \mathrm{~Hz}, 1 \mathrm{H}), 2.18$ $(\mathrm{s}, 3 \mathrm{H}) ;{ }^{13} \mathrm{C} \mathrm{NMR}\left(125 \mathrm{MHz}, \mathrm{CDCl}_{3}\right) \delta: 144.1,135.9$, $130.5,129.1,128.9,128.6,126.5,118.9,112.3,99.5,80.5$, 58.4, 28.1, 17.9. HRMS $\left(\mathrm{ESI}^{+}\right)$calcd for $\mathrm{C}_{16} \mathrm{H}_{18} \mathrm{NO}[\mathrm{M}+$ $\mathrm{H}]^{+}$240.1383, found 240.1380.

$N$-(4-Methoxyphenyl)isochroman-1-amine (3f): $:^{[7]}$ Yellow oil. ${ }^{1} \mathrm{H} \mathrm{NMR}\left(500 \mathrm{MHz}, \mathrm{CDCl}_{3}\right) \delta$ : $7.35(\mathrm{~d}, J=6.8 \mathrm{~Hz}$, $1 \mathrm{H}), 7.28$ (ddd, $J=9.9,5.3,3.8 \mathrm{~Hz}, 2 \mathrm{H}), 7.18$ (d, $J=7.6$ $\mathrm{Hz}, 1 \mathrm{H}), 6.86$ (s, 4H), $6.02(\mathrm{~d}, J=5.5 \mathrm{~Hz}, 1 \mathrm{H}), 4.39$ (d, $J=$ $5.5 \mathrm{~Hz}, 1 \mathrm{H}), 4.18$ (ddd, $J=11.7,9.2,4.1 \mathrm{~Hz}, 1 \mathrm{H}), 3.95 \sim$ $3.91(\mathrm{~m}, 1 \mathrm{H}), 3.80(\mathrm{~s}, 3 \mathrm{H}), 3.01 \sim 2.95(\mathrm{~m}, 1 \mathrm{H}), 2.83 \sim$ $2.78(\mathrm{~m}, 1 \mathrm{H}) ;{ }^{13} \mathrm{C} \mathrm{NMR}\left(125 \mathrm{MHz}, \mathrm{CDCl}_{3}\right) \delta: 153.2$, $140.0,135.9,135.2,129.1,128.1,127.1,126.6,115.4$, 115.2, 81.4, 58.6, 56.1, 28.6. HRMS (ESI $\left.{ }^{+}\right)$calcd for $\mathrm{C}_{16} \mathrm{H}_{18} \mathrm{NO}_{2}[\mathrm{M}+\mathrm{H}]^{+}$256.1332, found 256.1332.

$N$-(3-Methoxyphenyl)isochroman-1-amine (3g): Yellow oil. ${ }^{1} \mathrm{H}$ NMR $\left(500 \mathrm{MHz}, \mathrm{CDCl}_{3}\right) \delta: 7.34 \sim 7.26(\mathrm{~m}, 3 \mathrm{H})$, $7.21 \sim 7.16(\mathrm{~m}, 2 \mathrm{H}), 6.52 \sim 6.49(\mathrm{~m}, 2 \mathrm{H}), 6.45 \sim 6.42(\mathrm{~m}$, $1 \mathrm{H}), 6.08(\mathrm{~s}, 1 \mathrm{H}), 4.64(\mathrm{~s}, 1 \mathrm{H}), 4.19$ (ddd, $J=11.7,9.6,4.0$ $\mathrm{Hz}, 1 \mathrm{H}), 3.97 \sim 3.93(\mathrm{~m}, 1 \mathrm{H}), 3.83(\mathrm{~s}, 3 \mathrm{H}), 3.03 \sim 2.97(\mathrm{~m}$, $1 \mathrm{H}), 2.82 \sim 2.77(\mathrm{~m}, 1 \mathrm{H}) ;{ }^{13} \mathrm{C} \mathrm{NMR}\left(125 \mathrm{MHz}, \mathrm{CDCl}_{3}\right) \delta$ : $161.0,147.3,135.6,135.2,130.3,129.1,128.2,127.0$, $126.7,107.07,104.5,100.2,80.5,58.7,55.4,28.5$; IR $(\mathrm{KBr}) v: 3420,1608,1501,1450,1206,1152,1080,1044$, $820,750 \mathrm{~cm}^{-1}$. HRMS $\left(\mathrm{ESI}^{+}\right)$calcd for $\mathrm{C}_{16} \mathrm{H}_{18} \mathrm{NO}_{2}[\mathrm{M}+$ $\mathrm{H}^{+}$256.1332, found 256.1337.

$N$-(4-Fluorophenyl)isochroman-1-amine (3h): ${ }^{[8]}$ Yellow oil. ${ }^{1} \mathrm{H}$ NMR $\left(500 \mathrm{MHz}, \mathrm{CDCl}_{3}\right) \delta: 7.35 \sim 7.23(\mathrm{~m}, 4 \mathrm{H})$, $6.97(\mathrm{t}, J=8.7 \mathrm{~Hz}, 2 \mathrm{H}), 6.83(\mathrm{dd}, J=9.0,4.5 \mathrm{~Hz}, 2 \mathrm{H}), 6.01$ 
$(\mathrm{d}, J=7.8 \mathrm{~Hz}, 1 \mathrm{H}), 4.50(\mathrm{~d}, J=7.6 \mathrm{~Hz}, 1 \mathrm{H}), 4.17$ (ddd, $J=$ 11.7, 9.2, 4.1 Hz, $1 \mathrm{H}), 3.96 \sim 3.91(\mathrm{~m}, 1 \mathrm{H}), 3.01 \sim 2.95(\mathrm{~m}$, 1H), 2.81 (dt, $J=16.5,4.1 \mathrm{~Hz}, 1 \mathrm{H}) ;{ }^{13} \mathrm{C}$ NMR $(125 \mathrm{MHz}$, $\left.\mathrm{CDCl}_{3}\right) \delta: 156.2,142.0,135.3,135.0,128.9,128.0,126.7$, 126.5, 115.9, $115.7,80.8,58.5,28.3$. HRMS $\left(\mathrm{ESI}^{+}\right)$calcd for $\mathrm{C}_{15} \mathrm{H}_{15} \mathrm{FNO}[\mathrm{M}+\mathrm{H}]^{+}$244.1132, found 244.1132.

$N$-(4-Chlorophenyl)isochroman-1-amine (3i): ${ }^{[7-8]}$ Yellow oil. ${ }^{1} \mathrm{H}$ NMR $\left(500 \mathrm{MHz}, \mathrm{CDCl}_{3}\right) \delta: 7.31 \sim 7.26(\mathrm{~m}, 4 \mathrm{H})$, $7.21(\mathrm{~d}, J=8.8 \mathrm{~Hz}, 2 \mathrm{H}), 6.84 \sim 6.81(\mathrm{~m}, 2 \mathrm{H}), 6.03(\mathrm{~d}, J=$ $7.7 \mathrm{~Hz}, 1 \mathrm{H}), 4.62$ (d, $J=7.6 \mathrm{~Hz}, 1 \mathrm{H}), 4.15$ (ddd, $J=11.7$, 9.5, 4.1 Hz, 1H), 3.93 (ddd, $J=11.6,5.5,4.0 \mathrm{~Hz}, 1 \mathrm{H})$, $3.02 \sim 2.95(\mathrm{~m}, 1 \mathrm{H}), 2.79(\mathrm{dt}, J=16.5,3.9 \mathrm{~Hz}, 1 \mathrm{H}) ;{ }^{13} \mathrm{C}$ NMR $\left(125 \mathrm{MHz}, \mathrm{CDCl}_{3}\right) \delta: 144.5,135.9,135.2,129.4$, $129.2(\mathrm{~d}, J=11.6 \mathrm{~Hz}), 128.9,126.5,123.8,115.4$, 99.5, 80.5, 58.3, 28.1. HRMS (ESI ${ }^{+}$) calcd for $\mathrm{C}_{15} \mathrm{H}_{15} \mathrm{ClNO}$ $[\mathrm{M}+\mathrm{H}]^{+}$260.0837, found 260.0833 .

$N$-(4-Bromophenyl)isochroman-1-amine (3j): ${ }^{[8]}$ Yellow oil. ${ }^{1} \mathrm{H}$ NMR $\left(500 \mathrm{MHz}, \mathrm{CDCl}_{3}\right) \delta$ : $7.27(\mathrm{~d}, J=7.3 \mathrm{~Hz}$, $4 \mathrm{H}), 7.18(\mathrm{~s}, 2 \mathrm{H}), 6.78(\mathrm{~d}, J=8.8 \mathrm{~Hz}, 2 \mathrm{H}), 6.02(\mathrm{~d}, J=7.7$ $\mathrm{Hz}, 1 \mathrm{H}), 4.63$ (d, $J=7.6 \mathrm{~Hz}, 1 \mathrm{H}), 4.14$ (ddd, $J=11.7,9.5$, $4.0 \mathrm{~Hz}, 1 \mathrm{H}), 3.92$ (ddd, $J=11.6,5.5,4.0 \mathrm{~Hz}, 1 \mathrm{H}), 3.02 \sim$ $2.96(\mathrm{~m}, 1 \mathrm{H}), 2.78(\mathrm{dt}, J=16.6,3.9 \mathrm{~Hz}, 1 \mathrm{H}) ;{ }^{13} \mathrm{C} \mathrm{NMR}$ $\left(125 \mathrm{MHz}, \mathrm{CDCl}_{3}\right) \delta: 144.7,135.6,132.0,130.3,128.9$, $128.7,128.3,126.2,115.6,99.3,81.0,58.1,27.8$. HRMS $\left(\mathrm{ESI}^{+}\right.$) calcd for $\mathrm{C}_{15} \mathrm{H}_{15} \mathrm{BrNO}[\mathrm{M}+\mathrm{H}]^{+}$304.0332, found 304.0330 .

$\mathrm{N}$-(4-Iodophenyl)isochroman-1-amine (3k): Yellow oil. ${ }^{1} \mathrm{H}$ NMR $\left(500 \mathrm{MHz}, \mathrm{CDCl}_{3}\right) \delta: 7.54 \sim 7.50(\mathrm{~m}, 2 \mathrm{H}), 7.29$ (qd, $J=6.8,3.5 \mathrm{~Hz}, 3 \mathrm{H}), 7.19$ (d, $J=7.0 \mathrm{~Hz}, 1 \mathrm{H}), 6.68$ (d, $J=8.8 \mathrm{~Hz}, 2 \mathrm{H}), 6.03$ (d, $J=7.5 \mathrm{~Hz}, 1 \mathrm{H}), 4.62$ (d, $J=7.4$ $\mathrm{Hz}, 1 \mathrm{H}), 4.14$ (ddd, $J=11.7,9.6,4.0 \mathrm{~Hz}, 1 \mathrm{H}), 3.93$ (ddd, $J=11.6,5.5,3.9 \mathrm{~Hz}, 1 \mathrm{H}), 3.02 \sim 2.96(\mathrm{~m}, 1 \mathrm{H}), 2.79(\mathrm{dt}$, $J=16.6,3.9 \mathrm{~Hz}, 1 \mathrm{H}) ;{ }^{13} \mathrm{C} \mathrm{NMR}\left(125 \mathrm{MHz}, \mathrm{CDCl}_{3}\right) \delta$ : $145.6,138.2,135.2,129.2,128.4,126.9,126.8,116.5$, $80.3,58.7,28.5$; IR (KBr) v: 3403, 1593, 1501,1449, 1308, 1293, 1244, 1082, 1080, 1043, 1022, 982, 808, $749 \mathrm{~cm}^{-1}$. HRMS $\left(\mathrm{ESI}^{+}\right.$) calcd for $\mathrm{C}_{15} \mathrm{H}_{15} \mathrm{INO}[\mathrm{M}+\mathrm{H}]^{+} 352.0193$, found 352.0193 .

$N$-(3-Chlorophenyl)isochroman-1-amine (31): ${ }^{[7]}$ Yellow oil. ${ }^{1} \mathrm{H}$ NMR $\left(500 \mathrm{MHz}, \mathrm{CDCl}_{3}\right) \delta 7.33 \sim 7.26(\mathrm{~m}, 5 \mathrm{H})$, $7.20 \sim 7.17(\mathrm{~m}, 2 \mathrm{H}), 6.92(\mathrm{t}, J=2.1 \mathrm{~Hz}, 1 \mathrm{H}), 6.04(\mathrm{~d}, J=$ $7.6 \mathrm{~Hz}, 1 \mathrm{H}), 4.71(\mathrm{~d}, J=7.3 \mathrm{~Hz}, 1 \mathrm{H}), 4.15$ (ddd, $J=11.6$, 9.6, $4.0 \mathrm{~Hz}, 1 \mathrm{H}), 3.94$ (ddd, $J=11.6,5.5,3.9 \mathrm{~Hz}, 1 \mathrm{H})$, $3.03 \sim 2.96(\mathrm{~m}, 1 \mathrm{H}), 2.78(\mathrm{dt}, J=16.6,3.9 \mathrm{~Hz}, 1 \mathrm{H}) ;{ }^{13} \mathrm{C}$ NMR $\left(125 \mathrm{MHz}, \mathrm{CDCl}_{3}\right) \delta: 147.1,135.8,130.5,126.9$, $126.7,126.4,119.0,114.1,112.5,99.4,80.2$, 58.6, 28.4. HRMS $\left(\mathrm{ESI}^{+}\right.$) calcd for $\mathrm{C}_{15} \mathrm{H}_{15} \mathrm{CINO}[\mathrm{M}+\mathrm{H}]^{+} \quad 260.0837$, found 260.0837 .

$N$-(3-Bromophenyl)isochroman-1-amine (3m): Yellow oil. ${ }^{1} \mathrm{H}$ NMR (500 MHz, $\left.\mathrm{CDCl}_{3}\right) \delta: 7.32 \sim 7.27(\mathrm{~m}, 4 \mathrm{H})$, $7.19(\mathrm{t}, J=7.4 \mathrm{~Hz}, 2 \mathrm{H}), 7.12 \sim 7.07(\mathrm{~m}, 2 \mathrm{H}), 6.03(\mathrm{~d}, J=$ $7.6 \mathrm{~Hz}, 1 \mathrm{H}), 4.67$ (d, $J=7.7 \mathrm{~Hz}, 1 \mathrm{H}), 4.15$ (ddd, $J=11.7$, 9.6, $4.0 \mathrm{~Hz}, 1 \mathrm{H}), 3.94$ (ddd, $J=11.6,5.6,3.8 \mathrm{~Hz}, 1 \mathrm{H})$, $3.02 \sim 2.96(\mathrm{~m}, 1 \mathrm{H}), 2.78(\mathrm{dt}, J=16.5,3.8 \mathrm{~Hz}, 1 \mathrm{H}) ;{ }^{13} \mathrm{C}$ NMR $\left(125 \mathrm{MHz}, \mathrm{CDCl}_{3}\right) \delta: 147.3,135.8,135.1,130.8$, $126.9,126.8,126.4,123.5,122.0,117.0,112.9,99.5,80.2$, 58.6, 28.4; IR (KBr) v: 3409, 3372, 2991, 2918, 1595,
1496, 1378, 1304, 1290, 1119, 1098, 992, 900, 858, 749 $\mathrm{cm}^{-1}$. HRMS $\left(\mathrm{ESI}^{+}\right)$calcd for $\mathrm{C}_{15} \mathrm{H}_{15} \mathrm{BrNO}[\mathrm{M}+\mathrm{H}]^{+}$ 304.0332, found 304.0332.

$N$-(2-Nitrophenyl)isochroman-1-amine (3n): ${ }^{[10]}$ Yellow oil. ${ }^{1} \mathrm{H}$ NMR $\left(500 \mathrm{MHz}, \mathrm{CDCl}_{3}\right) \delta: 8.45(\mathrm{~d}, J=6.0 \mathrm{~Hz}$, $1 \mathrm{H}), 8.24$ (dd, $J=8.6,1.6 \mathrm{~Hz}, 1 \mathrm{H}), 7.57$ (ddd, $J=8.4,7.2$, $1.3 \mathrm{~Hz}, 1 \mathrm{H}), 7.45(\mathrm{~d}, J=8.0 \mathrm{~Hz}, 1 \mathrm{H}), 7.34 \sim 7.27(\mathrm{~m}, 4 \mathrm{H})$, 6.86 (ddd, $J=8.4,7.0,1.2 \mathrm{~Hz}, 1 \mathrm{H}), 6.19$ (d, $J=6.6 \mathrm{~Hz}$, $1 \mathrm{H}), 4.19 \sim 4.13(\mathrm{~m}, 1 \mathrm{H}), 3.98(\mathrm{ddd}, J=11.6,5.7,3.0 \mathrm{~Hz}$, $1 \mathrm{H}), 3.07$ (dd, $J=11.2,5.4 \mathrm{~Hz}, 1 \mathrm{H}), 2.82(\mathrm{dd}, J=11.6,8.3$ $\mathrm{Hz}, 1 \mathrm{H}) ;{ }^{13} \mathrm{C} \mathrm{NMR}\left(125 \mathrm{MHz}, \mathrm{CDCl}_{3}\right) \delta: 143.5,136.2$, $134.7,133.8,129.1,128.5,126.9,126.6,117.4,116.0$, 99.3, 79.0, 58.7, 28.1. HRMS (ESI ${ }^{+}$) calcd for $\mathrm{C}_{15} \mathrm{H}_{15} \mathrm{~N}_{2} \mathrm{O}_{3}$ $[\mathrm{M}+\mathrm{H}]^{+}$271.1077, found 271.1070.

4-(Isochroman-1-ylamino)benzonitrile (3o): Colorless oil. ${ }^{1} \mathrm{H}$ NMR $\left(500 \mathrm{MHz}, \mathrm{CDCl}_{3}\right) \delta: 7.50 \sim 7.46(\mathrm{~m}, 2 \mathrm{H})$, $7.33 \sim 7.21(\mathrm{~m}, 4 \mathrm{H}), 6.90 \sim 6.87(\mathrm{~m}, 2 \mathrm{H}), 6.05(\mathrm{~d}, J=7.4$ $\mathrm{Hz}, 1 \mathrm{H}), 5.27(\mathrm{~d}, J=7.3 \mathrm{~Hz}, 1 \mathrm{H}), 4.13 \sim 4.07(\mathrm{~m}, 1 \mathrm{H})$, $3.92(\mathrm{ddd}, J=11.6,5.6,3.6 \mathrm{~Hz}, 1 \mathrm{H}), 3.02 \sim 2.95(\mathrm{~m}, 1 \mathrm{H})$, $2.75(\mathrm{dt}, J=16.6,3.7 \mathrm{~Hz}, 1 \mathrm{H}) ;{ }^{13} \mathrm{C} \mathrm{NMR}(125 \mathrm{MHz}$, $\left.\mathrm{CDCl}_{3}\right) \delta: 149.5,139.7,134.9,133.8,128.0,126.7,125.4$, $120.3,114.0,100.8,79.4,58.7$, 28.2; IR (KBr) v: 3352, 2921, 2898, 2210, 1706, 1602, 1509, 1323, 1297, 1180, 1122, 1088, 1024, 992, 820, $749 \mathrm{~cm}^{-1}$. HRMS (ESI $\left.{ }^{+}\right)$ calcd for $\mathrm{C}_{16} \mathrm{H}_{15} \mathrm{~N}_{2} \mathrm{O}[\mathrm{M}+\mathrm{H}]^{+}$251.1179, found 251.1170.

2-(Isochroman-1-ylamino)benzonitrile (3p): Colorless oil. ${ }^{1} \mathrm{H}$ NMR (500 MHz, $\left.\mathrm{CDCl}_{3}\right) \delta: 7.52 \sim 7.47(\mathrm{~m}, 2 \mathrm{H})$, 7.31 (qd, $J=7.2,2.0 \mathrm{~Hz}, 3 \mathrm{H}), 7.23(\mathrm{dd}, J=13.9,8.0 \mathrm{~Hz}$, $2 \mathrm{H}), 6.86(\mathrm{td}, J=7.8,0.8 \mathrm{~Hz}, 1 \mathrm{H}), 6.12(\mathrm{~d}, J=7.1 \mathrm{~Hz}$, $1 \mathrm{H}), 5.38$ (d, $J=6.9 \mathrm{~Hz}, 1 \mathrm{H}), 4.15$ (ddd, $J=11.5,10.3,3.8$ $\mathrm{Hz}, 1 \mathrm{H}), 3.95$ (ddd, $J=11.6,5.7,3.2 \mathrm{~Hz}, 1 \mathrm{H}$ ), 3.04 (ddd, $J=16.1,10.1,5.7 \mathrm{~Hz}, 1 \mathrm{H}), 2.80(\mathrm{dt}, J=16.6,3.5 \mathrm{~Hz}, 1 \mathrm{H})$; ${ }^{13} \mathrm{C} \mathrm{NMR}\left(125 \mathrm{MHz}, \mathrm{CDCl}_{3}\right) \delta: 148.6,134.6,132.9,129.3$, $128.7,127.1,127.0,118.8,113.5,79.6,58.7,28.3$; IR (KBr) v: 3402, 2918, 2888, 2210, 1601, 1581, 1504, 1450, 1318, 1297, 1091, 1022, $749 \mathrm{~cm}^{-1}$. HRMS $\left(\mathrm{ESI}^{+}\right) \mathrm{calcd}$ for $\mathrm{C}_{16} \mathrm{H}_{15} \mathrm{~N}_{2} \mathrm{O}[\mathrm{M}+\mathrm{H}]^{+}$251.1179, found 251.1179.

$\mathrm{N}$-(4-(Trifluoromethyl)phenyl)isochroman-1-amine (3q): Yellow oil. ${ }^{1} \mathrm{H}$ NMR $\left(500 \mathrm{MHz}, \mathrm{CDCl}_{3}\right) \delta$ : 7.51 (d, $J=8.5 \mathrm{~Hz}, 2 \mathrm{H}), 7.34 \sim 7.27(\mathrm{~m}, 4 \mathrm{H}), 6.94(\mathrm{~d}, J=8.5 \mathrm{~Hz}$, 2H), 6.10 (d, $J=4.9 \mathrm{~Hz}, 1 \mathrm{H}), 4.94$ (s, 1H), 4.15 (ddd, $J=$ 11.6, 9.8, 4.0 Hz, 1H), 3.95 (ddd, $J=11.6,5.5,3.8 \mathrm{~Hz}$, $1 \mathrm{H}), 3.05 \sim 2.98(\mathrm{~m}, 1 \mathrm{H}), 2.79(\mathrm{dt}, J=16.6,3.7 \mathrm{~Hz}, 1 \mathrm{H})$. ${ }^{13} \mathrm{C}$ NMR $\left(125 \mathrm{MHz}, \mathrm{CDCl}_{3}\right) \delta: 148.6,135.8,135.1,129.3$, $129.1,128.9,128.5,126.5,113.6,99.5,79.9,58.7,28.4$; IR (KBr) v: 3353, 2981, 2918, 1708, 1606, 1516, 1499, 1472, 1319, 1150, 1104, 1053, 1022, 816, $749 \mathrm{~cm}^{-1}$. HRMS $\left(\mathrm{ESI}^{+}\right.$) calcd for $\mathrm{C}_{16} \mathrm{H}_{15} \mathrm{~F}_{3} \mathrm{NO}[\mathrm{M}+\mathrm{H}]^{+}$294.1100, found 294.1109 .

$N$-(3,5-Dichlorophenyl)isochroman-1-amine (3r): Yellow oil. ${ }^{1} \mathrm{H}$ NMR $\left(500 \mathrm{MHz}, \mathrm{CDCl}_{3}\right) \delta: 7.31 \sim 7.26(\mathrm{~m}$, 4H), 7.19 (t, $J=7.8 \mathrm{~Hz}, 2 \mathrm{H}), 7.01$ (d, $J=2.7 \mathrm{~Hz}, 1 \mathrm{H}), 5.99$ $(\mathrm{d}, J=7.5 \mathrm{~Hz}, 1 \mathrm{H}), 4.69$ (d, $J=7.5 \mathrm{~Hz}, 1 \mathrm{H}), 4.12$ (ddd, $J=$ $11.7,9.6,4.0 \mathrm{~Hz}, 1 \mathrm{H}$ ), 3.93 (ddd, $J=11.6,5.5,3.9 \mathrm{~Hz}$, $1 \mathrm{H}), 3.02 \sim 2.96(\mathrm{~m}, 1 \mathrm{H}), 2.78(\mathrm{dt}, J=16.6,3.9 \mathrm{~Hz}, 1 \mathrm{H})$; ${ }^{13} \mathrm{C} \mathrm{NMR}\left(125 \mathrm{MHz}, \mathrm{CDCl}_{3}\right) \delta: 145.5,135.8,135.1,129.2$, $128.5,126.5,115.6,114.0,99.5,80.2,58.7,28.0$; IR (KBr) 
$v: 3420,3353,2980,2919,1598,1499,1491,1301,1082$, 1050, 1022, 996, $749 \mathrm{~cm}^{-1}$. HRMS $\left(\mathrm{ESI}^{+}\right)$calcd for $\mathrm{C}_{15} \mathrm{H}_{14} \mathrm{Cl}_{2} \mathrm{NO}[\mathrm{M}+\mathrm{H}]^{+}$294.0447, found 294.0441.

$\mathrm{N}$-(3,5-Bis(trifluoromethyl)phenyl)isochroman-1-amine (3s): ${ }^{[8]}$ Yellow oil. ${ }^{1} \mathrm{H}$ NMR $\left(500 \mathrm{MHz}, \mathrm{CDCl}_{3}\right) \delta: 7.39$ (d, $J=7.5 \mathrm{~Hz}, 1 \mathrm{H}), 7.33 \sim 7.27(\mathrm{~m}, 4 \mathrm{H}), 7.20(\mathrm{dd}, J=18.8$, $7.5 \mathrm{~Hz}, 2 \mathrm{H}), 6.09$ (d, $J=7.4 \mathrm{~Hz}, 1 \mathrm{H}), 5.05$ (d, $J=7.2 \mathrm{~Hz}$, $1 \mathrm{H}), 4.13$ (ddd, $J=11.6,10.0,3.9 \mathrm{~Hz}, 1 \mathrm{H}), 4.01 \sim 3.93(\mathrm{~m}$, 1H), 3.04 (ddd, $J=17.1,12.0,5.4 \mathrm{~Hz}, 1 \mathrm{H}), 2.79$ (dt, $J=$ 16.6, 3.6 Hz, $1 \mathrm{H}) ;{ }^{13} \mathrm{C} \mathrm{NMR}\left(125 \mathrm{MHz}, \mathrm{CDCl}_{3}\right) \delta: 146.84$, $135.1,134.3,132.6,129.1,128.9,126.8,126.5,124.9$, 124.7, 99.5, 79.9, 58.3, 28.1. HRMS (ESI $\left.{ }^{+}\right)$calcd.for $\mathrm{C}_{17} \mathrm{H}_{14} \mathrm{~F}_{6} \mathrm{NO}[\mathrm{M}+\mathrm{H}]^{+}$362.0974, found 362.0979.

$N$-(Naphthalen-2-yl)isochroman-1-amine (3t): ${ }^{[7]}$ Yellow oil. ${ }^{1} \mathrm{H}$ NMR $\left(500 \mathrm{MHz}, \mathrm{CDCl}_{3}\right) \delta: 7.83 \sim 7.63(\mathrm{~m}, 3 \mathrm{H})$, $7.46 \sim 7.39(\mathrm{~m}, 1 \mathrm{H}), 7.37(\mathrm{~d}, J=7.6 \mathrm{~Hz}, 1 \mathrm{H}), 7.35 \sim 7.27$ (m, 4H), $7.22(\mathrm{~d}, J=7.4 \mathrm{~Hz}, 1 \mathrm{H}), 7.05(\mathrm{dd}, J=8.8,2.3 \mathrm{~Hz}$, $1 \mathrm{H}), 6.23$ (d, $J=7.5 \mathrm{~Hz}, 1 \mathrm{H}), 4.77$ (d, $J=7.4 \mathrm{~Hz}, 1 \mathrm{H}), 4.22$ (ddd, $J=11.6,9.8,3.9 \mathrm{~Hz}, 1 \mathrm{H}), 3.99$ (ddd, $J=11.6,5.6$, $3.7 \mathrm{~Hz}, 1 \mathrm{H}), 3.10 \sim 2.98(\mathrm{~m}, 1 \mathrm{H}), 2.82(\mathrm{dt}, J=16.6,3.7$ $\mathrm{Hz}, 1 \mathrm{H}) ;{ }^{13} \mathrm{C} \mathrm{NMR}\left(126 \mathrm{MHz}, \mathrm{CDCl}_{3}\right) \delta: 143.34$ (s), 135.33 (s), 134.99 (s), 129.09 (s), 128.97 (s), 128.24 (s), 128.06 (s), 127.64 (s), 126.88 (s), 126. 25 (s), 126.38 (s), 122.63 (s), 117.65 (s), 107.07 (s), 80.35 (s), 58.37 (s), 28.31 (s). HRMS (ESI ${ }^{+}$) calcd for $\mathrm{C}_{19} \mathrm{H}_{18} \mathrm{NO}[\mathrm{M}+\mathrm{H}]^{+}$ 276.1383 , found 276.1390 .

Isochroman-1-one (4): ${ }^{[11]}$ Colorless oil. ${ }^{1} \mathrm{H}$ NMR (300 $\left.\mathrm{MHz}, \mathrm{CDCl}_{3}\right) \delta: 8.10(\mathrm{~d}, J=7.5 \mathrm{~Hz}, 1 \mathrm{H}), 7.42$ (ddd, $J=$ 41.4, 23.9, $6.8 \mathrm{~Hz}, 3 \mathrm{H}), 4.72 \sim 4.45(\mathrm{~m}, 2 \mathrm{H}), 3.23 \sim 2.97$ $(\mathrm{m}, 2 \mathrm{H}) ;{ }^{13} \mathrm{C}$ NMR $\left(75 \mathrm{MHz}, \mathrm{CDCl}_{3}\right) \delta: 165.4,139.8$, $133.9,130.6,127.9,127.5,125.5,67.6,28.1$.

Supporting Information ESI-MS spectra of imine intermediate and copies of ${ }^{1} \mathrm{H}$ NMR and ${ }^{13} \mathrm{C}$ NMR spectra of compounds 3 and 4. The Supporting Information is available free of charge via the Internet at http://sioc-journal. $\mathrm{cn} /$.

\section{References}

[1] (a) Xu, Z.; Zheng, Y.; Wang, Z.; Shao, X.; Wang, Y. Chem. Commun. 2019, 55, 15089 .

(b) Nasresfahani, Z.; Kassaee, M. Z. Appl. Organomet. Chem. 2021, 35(1), e6032.

(c) Luo, N. H.; Zhong, Y. H.; Wen, H. L.; Luo, R. ACS Omega 2020, 5, 27723.

[2] (a) Ghorai, M. K.; Nanaji, Y. J. Org. Chem. 2013, 78, 3867.

(b) Larsen, A. F.; Ulven, T. Chem. Commun. 2014, 50, 4997.

(c) Xie, J. W.; Wang, X. C.; Wu, F. T.; Zhang, J. Chin. J. Org. Chem. 2019, 39, 3026 (in Chinese).

(谢建伟, 汪小创, 吴丰田, 张洁, 有机化学, 2019, 39, 3026.)

(d) Yao, D. D.; Zhang, J. L.; Xu, L. Chin. J. Org. Chem. 2020, 40, 1673 (in Chinese).

(姚丹丹，张金利，徐亮，有机化学, 2020, 40, 1673.)
[3] (a) Irrgang, T.; Kempe, R. Chem. Rev. 2020, 120, 9583.

(b) Montes-Andrés, H.; Leo, P.; Muñoz, A.; Rodríguez-Diéguez, A.; Orcajo, G.; Choquesillo-Lazarte, D.; Martos, C.; Martínez, F.; Botas, J. A.; Calleja, G. Inorg. Chem. 2020, 59, 15733.

(c) Bhoge, B. A.; Mala, P.; Kurian, J. S.; Srinivasan, V.; Saraogi, I. Chem. Commun. 2020, 56, 13832.

(d) Ravi, K.; Advani, J. H.; Bankar, B. D.; Singh, A. S.; Biradar, A. V. New J. Chem. 2020, 44, 18714.

(e) Petersen, A. R.; Lauridsen, J. M. V.; Lee, J. W. Eur. J. Org. Chem. 2020, 47, 7368.

(f) Yan, F.; Cai, S.; Wen, W.; Wen, W.; Li, B. J.; Wang, L. S.; Zhu, L. Chin. J. Org. Chem. 2020, 40, 1874 (in Chinese).

(严泮，蔡爽，闻武，文蔚，李博解，汪连生，朱否，有机化学， 2020, 40, 1874.)

[4] (a) Aneeja, T.; Neetha, M.; Afsinaa, C. M. A.; Anilkumar, G. RSC Adv. 2020, 10,34429 .

(b) Anastas, P.; Eghbali, N. Chem. Soc. Rev. 2010, 39, 301.

(c) Wang, G.; Wang, J. T.; Zhao, B.; Chen, H.; Zhang, P. K.; Han, S. L. Tetrahedron Lett. 2020, 61, 151426.

(d) Zhang, X. L.; Pan, G. F.; Zhu, X. Q.; Guo, R. L.; Gao, Y. R.; Wang, Y. Q. Org. Lett. 2019, 21, 2731.

(e) Baslé, O.; Li, C. J. Chem. Commun. 2009, 27, 4124.

(f) Boess, E.; Schmitz, C.; Klussmann, M. J. Am. Chem. Soc. 2012 134, 5317.

(g) Wusiman, A.; Hudabaierdi, R. Tetrahedron Lett. 2019, 60,681.

(h) Liu, Y. X.; Wang, C.; Xue, D.; Xiao, M.; Li, C. Q.; Xiao, J. L. Chem.-Eur. J. 2017, 23, 3051.

(i) Brzozowski, M.; Forni, J. A.; Savage, G. P.; Polyzos, A. Chem. Commun. 2015, 51, 334.

(j) Sun, Y. M.; Ding, Q. F.; Yu, Y.; He, Y. D.; Huang, F. Chin. J. Org. Chem. 2019, 39, 3363 (in Chinese)

(孙义明，丁奇峰，于杨，何益得，黄菲，有机化学， 2019，39, 3363.)

(k) Rana, P.; Gaur, R.; Gupta, R.; Arora, G.; Jayashree, A.; Sharama, R. K. Chem. Commun. 2019, $55,7402$.

(1) Xie, J.; Li, H. M.; Zhou, J. C.; Cheng, Y. X.; Zhu, C. J. Angew. Chem. Int. Ed. 2012, 51, 1252.

(m) Ratnikov, M. O.; Doyle, M. P.; J. Am. Chem. Soc. 2013, 135, 1549.

(n) Patil, M. R.; Dedhia, N. P.; Kapdi, A. R.; Kumar, A. V. J. Org. Chem. 2018, 83, 4477.

(o) Kumar, R. A.; Saidulu, G.; Prasad, K. R.; Kumar, G. S.; Sridhar, B.; Reddy, K. R. Adv. Synth. Catal. 2012, 354, 2985.

(p) Cao, M.; Mao, Y.; Huang, J. C.; Ma, Y. D.; Liu, L. Tetrahedron Lett. 2019, 60, 1075 .

[5] (a) Martin, P.; Consroe, P. Science 1976, 194, 965. (b) Groot, M. J. D.; Alex, A. A.; Jones, B. C. J. Med. Chem. 2002, 45, 1983.

(c) Yamaori, S.; Kushihara, M.; Yamamoto, I.; Watanabe, Y. Biochem. Pharmacol. 2010, 79, 1691.

[6] (a) Lehmann, F.; Pettersen, A.; Currier, E. A.; Sherbukhin, V.; Olsson, R.; Hacksell, U., Luthman, K. J. Med. Chem. 2006, 49, 2232. (b) Maier, C. A.; Wünsch, B. J. Med. Chem. 2002, 45, 438

[7] Feng, J.; Lv, M. F.; Lu, G. P.; Cai, C. Org. Chem. Front. 2015, 2, 60.

[8] Chen, D.; Pan, F.; Gao, J.; Yang, J. Synlett 2013, 24, 2085.

[9] (a) Zhou, W. Y.; Lu, W. M. Z.; Wang, H.; Xia, Z. Z.; Zhai, S. Y.; Zhang, Z.; Ma, Y. J.; He, M. Y.; Chen, Q. Appl. Catal. A, Gen. 2020, 604, 117771

(b) Sun, Z. H.; Xia, Z. Z.; Wang, A. W.; Wang, H.; Zhang Z.; Zhou, W. Y.; Qian, J. F.; He, M. Y. Tetrahedron Lett. 2020, 61, 152254

[10] Chen, Z. W.; Liu, B. T.; Liang, P.; Luo, H. Q.; Zheng, J.; Wen, X. W.; Liu, T. G.; Luo, G. T.; Ye, M. ACS Omega 2019, 4, 281.

[11] Kumar, R. A.; Maheswari, C. U.; Ghantasala, S.; Jyothi, C.; Reddy, K. R. Adv. Synth. Catal. 2011, 353, 401. 